\title{
“いわゆる女性型肺癌”について
}

\section{The So-called "Female type" of Lung Cancer}

佐藤秩子

要旨：原発性肺癌をいわゆる男性型と女性型に 2 大分別して比較検討した。女性型は, 現在の 我が国の女性肺癌の大部分を占め, 喫煙男性にもみられるが，喫煙など外因の影響によ るとは考之られない肺癌である。比較的末梢の気道上皮から発生し, 腺癌像が優勢で, その発生年齢は細胞型亜型，性にかかわらず男性型より有意に若い。発育尖端の進展様 式は肺胞内浸潤型が大部分である。これらの点もふまえ, 組織分類としての細気管支肺 胞上皮癌の存在意義についても考察した。

〔肺癌 $25(1): 1 \sim 11,1985$ 〕

Key words : Female lung cancer, Adenocarcinoma of the lung,

Bronchiolo-alveolar cell carcinoma.

\section{はじめに}

原発性肺癌は, その発生と喫煙との関連から しても，“男の癌”という印象が強い1）事実最近 5 年間の日本病理剖検輯報による剖検肺癌 14000 例のうち，男性例はその75\%を占めている? 契 煙習慣の少い日本の大方の女性にとって肺癌は “無縁のもの„との考えが支配的であったことは 否めない。すでに著者らは自験例の検討から， 比較的肺門発生で喫煙とも関連し, 扁平上皮癌 像が優勢で，比較的高齢者にみられる“男性型 肺癌”とでも呼ぶべきグループと, 比較的末梢 発生で，若年者に多く，喫煙とは関係の少い, 腺癌像を支配とする “女性型肺癌”, とでも呼ぶ べきグループのあることを提唱して来たざ-6)

本報告では“いわゆる女性型肺癌”, に焦点を あて, 男性型と対比しつつ, 発生( 部位, 年齢, 契煙との関連), 進展についての形態学的分析検 討を試みた結果を中心に，考察を加えたい。

愛知県がんセンタ一臨床検査部

\section{検索材料, 方法}

1960年から1983年 6 月までの愛知県がんセン 夕一病院に招ける外科手術剔出例(男300例, 女 109例)で，術前治療などで組織像の変貌したも のは除いた、気管支より10倍フォルマリンを注 入して膨らませた状態で肺を固定したのち，5 $\mathrm{mm}$ 厚のスライスを作製，癌塊の最大径の含ま れるスライスから，非癌部を立分含めた大割切 片を作製した。H-E重染色，用にのぞんでアル シアンブルー H·E 重染色, Weigert 氏弾力線維 染色を施した。 又腺癌例より40例, 他の癌組織 型例から10例をえらび，酵素抗体法間接法によ り組織学的に細胞内 CEAの検出を試みた.

新鮮材料或いは10倍フォルマリン固定後, 癌 組織細片をグルタールアルデヒドーオスミウム 固定, エポン包埋し, 厚切り切片の光顕的観察 を経て電顕的検索を行った。

腺癌について 2 型の細胞型覀型分類を行った。 即ち，立方形一円柱状を呈し，互いに密に接し て腺腔を形成する細胞型と, 棍棒状を呈し, 相 互よりもむしろ間質と個々密に接することが多 い細胞型との 2 型である(Fig. 1 )。 
Fig. 1. Cell types of adenocarcinoma

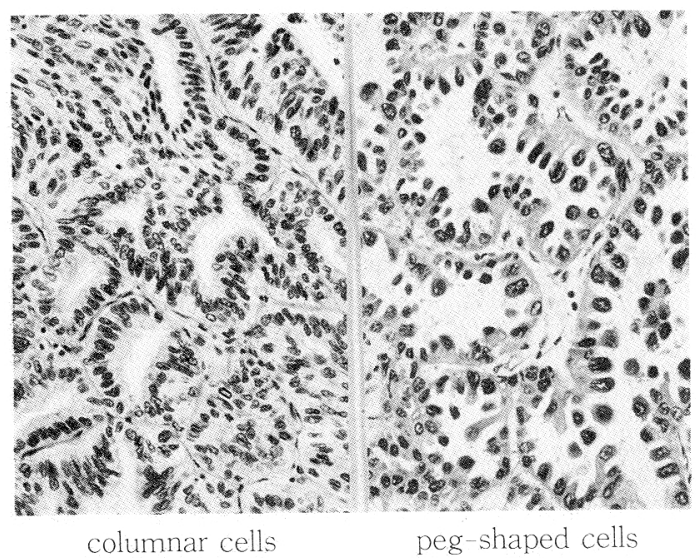

肺癌の肺野に扔ける発育尖端部の進展様相に ついて，田内らが告でに報告しているように， 肺野と尖端部との形態学的関連により, 次の 4 型に分類した。

1. 圧排性一肺胞壁を压排し, 肺胞構造を破壞 しての增殖進展。

2.肺胞内浸潤性一肺胞壁を破壞することなく 隣接の肺胞へとひろがるもので，腔旮奏型之内 壁を内べりするように進展する壁被覆型との2 垔型に动计大。

3. 間質性一気管支，血管周囲の結合織ないし リンパ管内に浸潤進展するもの.

以上のような進展梯相とその部の癌組織像と の組合女を求め, 各癌組織像, 各進展様式毎に, その組合せの発現頻度を求めた。

八ワイの女性肺癌例 :

私どもの外科手術例では，女性喫煙者が僅少 で比較が出来ないため, フィりッピン系, 八ワ 亿系女性に喫煙者の多い，八ワ亿女性肺癌例 ${ }^{2}$ の検討を行う機会を得ることが出来た。ホノル ル・クワキ二病院の G.N.Stemmermann 博士, クイーン病院の並木秀男博上の御厚意による130 例, さらに高齢喫煙者肺癌例の多い, 東京都盖 育院付属病院病理の女性肺癌剖検例28例も, 嶋 田裕之博士，木村雄二博士の御厚意により，自 験例と同様の形態学的分析を行うことが出来た。
Table 1. Age adjusted relative risk in squamous cell carcinoma of lung cancer in relation to cigarette smoking.

\begin{tabular}{lc}
\hline $\begin{array}{c}\text { relative risk to non-smokers and light smokers } \\
\text { (less than } 1 \text { pack/day) }\end{array}$ & \begin{tabular}{c} 
males \\
\cline { 2 - 2 }
\end{tabular} \\
\hline hilar & $3.41^{* *}$ \\
truncus intermedius, segmental & $3.16^{* *}$ \\
subsegmental & $4.04^{* *}$ \\
peripheral & $5.52^{* *}$ \\
total & $3.67^{* *}$ \\
\hline$* *$ p $<0.01$ & \\
Mantel-Haenszel method, age class, $-54.55-64,65-$ \\
cases = surgical resected materials of Aichi Cancer Ctr. Hos- \\
pital. \\
control = Health examination for Nagoya city residents, 1973
\end{tabular}

\section{検討成績}

量的に優勢な癌組織像をもって，それぞれの 症例を代表させ, 発生部位, 年齢, 喫煙歴, 男 女別に記入したのがFig. 2 である。又発生部位 別, 或いは喫煙歴別の肺癌組織型の発現頻度を Fig. 3-A,Bに示した。

検索材料が手術剔出例のため, 全肺癌例から みれば，肺門部発生の症例は比較的少くなって いる，女性例は殆んど末梢，喫煙歴(一)のとこ ろに集中し，男性例でも喫煙歴(一)の部に扁平 上皮癌例は及られない。

部位別或いは喫煙歴別に夫久の癌組織型の発 現頻度を求めると, 女性例では腺癌例が全例中 $80 \%$ を占める。このうち喫煙歴(一)の腺癌は63 $\%$ ，発生部位別にみる上末梢発生の腺癌は $67 \%$ で，喫煙歴の亦る女性例はあまりにも少い(Fig. 3-B)。喫煙之肺癌相対危険度については, 現在 の年龄により補正，喫煙者を非喫煙者（名古屋 市住民）上比較し，喫煙に上る相対危険度をみ た。届平上皮癌に対方方男性喫煙者の危険度は， (東北大公衆衛生清水弘之氏の厚意に上る) 方べ ての部位発生で, 3.4倍〜 5.5倍で非喫煙者との 間に有意差がみとめられた(Table 1)。一方，喫 煙者に扔ける腺癌発生相対危険度をみると, 男 性例で, すべての部位発生で, 非喫煙者との間 に有意差をみとめることが出来なかった。女性 喫煙者は，自験例ではあまりに少く推計処理を 
Fig. 2. Distribution of lung cancer caces according to smoking habit, site of origin, age $\&$ sex.

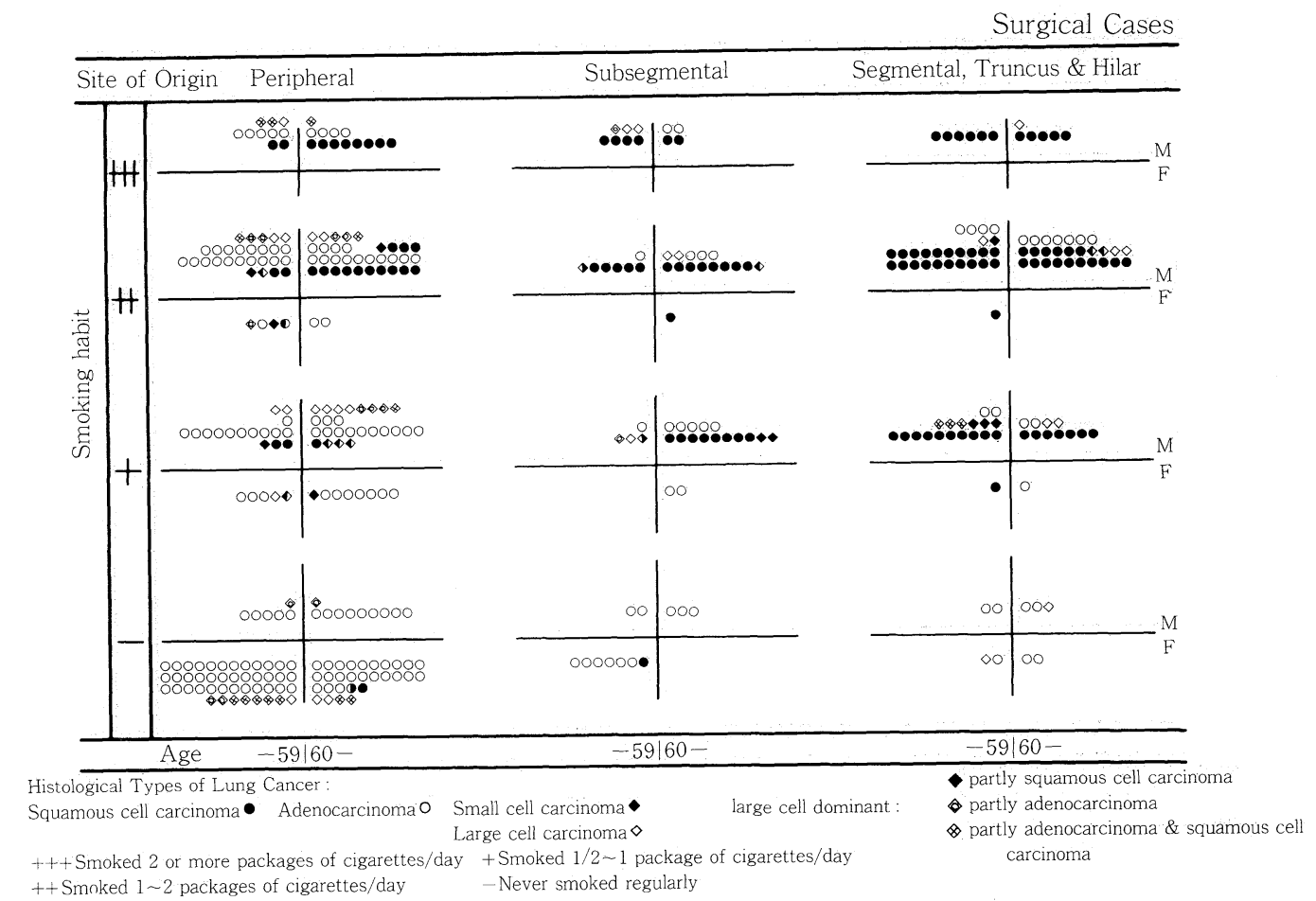

Fig. 3. Frequency of histologic type according to smoking habits \& site of origin.

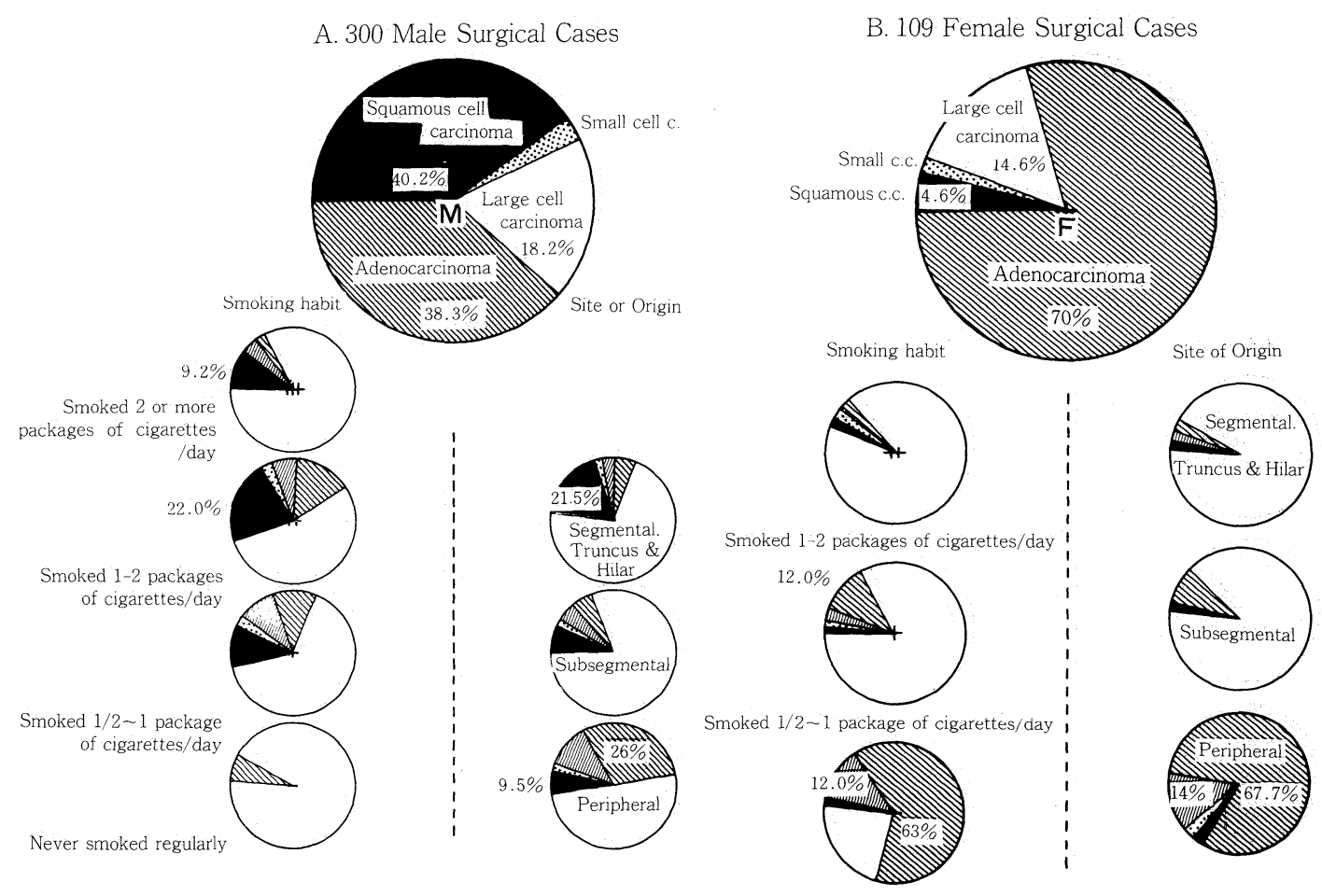


Fig. 4. Relationship between histological type of female lung cancer, smoking habit and age.

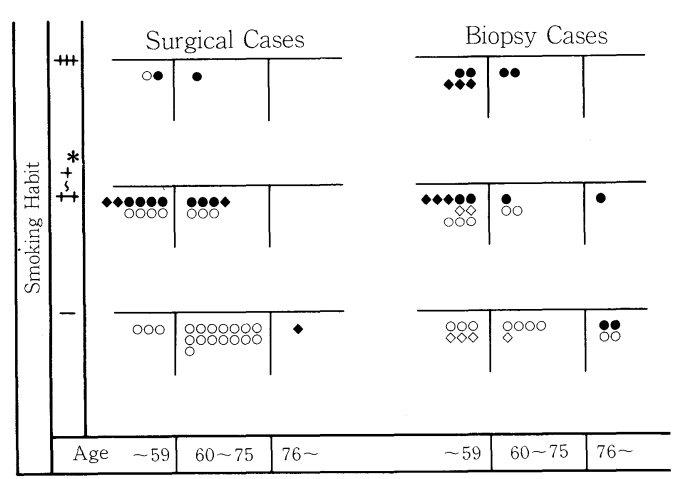

Fig. 5. Relationship between histological type of lung cancer, smoking habit and age in female autopsy cases.

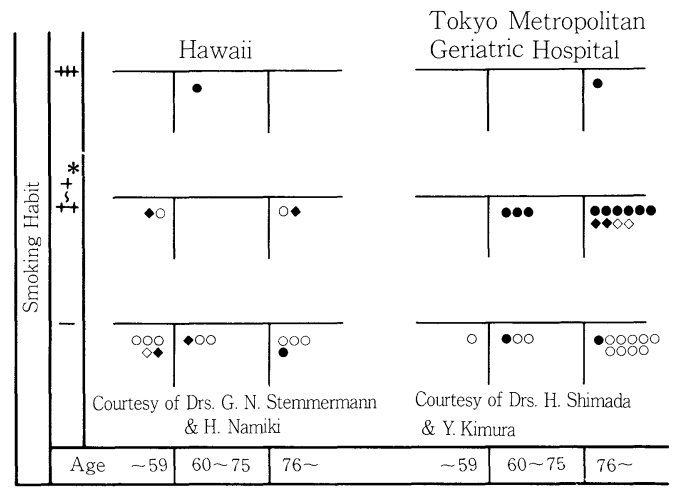

Histological Types of Lung Cancer : Squamous cell carcinoma

Adenocarcinoma S Small cell carcinoma +++ Smoked 2 or more packages of cigarettes/day + Smoked 1/2 1 packages of cigarettes/day + Smoked 1 2 packages of cigarettes/day

* including : Smoked cigarettes (amount was unknown) - Never smoked regularly

Large cell carcinoma $\diamond$

Table 2. Age adjusted relative risk in adenocarcinoma of lung cancer in relation to cigarette smoking.

\begin{tabular}{ccccc}
\hline \multicolumn{4}{c}{ relative risk to non smokers and light smokers (less than 1 pack/day) } \\
\hline & males & females & males & females \\
\hline hilar \& & & & & \\
subsegmental & 0.93 & 0.59 & 1.36 & \\
peripheral & 1.40 & 1.25 & 1.40 & 1.97 \\
total & 1.16 & 1.13 & 1.38 & 1.57 \\
\hline
\end{tabular}

Mantel-Haenszel method, age class, -54, 55-64, 65-

Table 3. Site of origin and cell types of adenocarcinoma of the lung.

\begin{tabular}{|c|c|c|c|c|}
\hline \multirow{2}{*}{$\begin{array}{l}\text { cell types } \\
\text { site of origin }\end{array}$} & \multicolumn{2}{|c|}{ males } & \multicolumn{2}{|c|}{ females } \\
\hline & columnar & peg-shaped & columnar & peg-shaped \\
\hline truncus intermedius & $2(4.1 \%)$ & $2(6.1 \%)$ & $1(3.2 \%)$ & 0 \\
\hline segmental & $11(22.4 \%)$ & $1(3.0 \%)$ & $1(3.2 \%)$ & $2(7.4 \%)$ \\
\hline subsegmental & $13(26.5 \%)$ & $5(15.2 \%)$ & $4(12.9 \%)$ & $2(7.4 \%)$ \\
\hline peripheral & $23(46.9 \%)$ & $25(75.8 \%)$ & $25(80.0 \%)$ & $23(85.2 \%)$ \\
\hline total & 49 & 33 & 31 & 27 \\
\hline
\end{tabular}

行い得なかった(Table 2 ).

八ワイに打ける女性肺癌例の検討では, 喫煙 者に扁平上皮癌, 小細胞癌がみられ, 腺癌は非 契煙者にもっとも多いが，喫煙者にもみられる という，自験例の男性例と同様の傾向を示した
(Fig. 4)。ついで東京都盖育院付属病院病理の 28例の女性肺癌剖検例についての同様の検討で も，喫煙者には男性と同様に扁平上皮癌，小細 胞癌がみとめられた(Fig. 5 ).

腺癌例を円柱状細胞型, 棍棒状細胞型の 2 亜 
Table 4. Frequency in appearance of transitional pictures of other histological types in adenocarcinoma of the lung.

\begin{tabular}{|c|c|c|c|c|}
\hline \multirow{2}{*}{ cell types } & \multicolumn{2}{|c|}{ males } & \multicolumn{2}{|c|}{ females } \\
\hline & columnar & peg-shaped & columnar & peg-shaped \\
\hline \multicolumn{5}{|l|}{$\begin{array}{l}\text { transitional pictures } \\
\text { to other histological types }\end{array}$} \\
\hline$(-)$ & $26(53.1 \%)$ & $29(87.9 \%)$ & $14(45.2 \%)$ & $24(88.9 \%)$ \\
\hline$(+)$ & $23(46.9 \%)$ & $4(12.1 \%)$ & $17(54.8 \%)$ & $3(11.1 \%)$ \\
\hline total & 49 & 33 & 31 & 27 \\
\hline
\end{tabular}

Fig. 6. Cell types and histological pattern of adenocarcinoma of the lung.

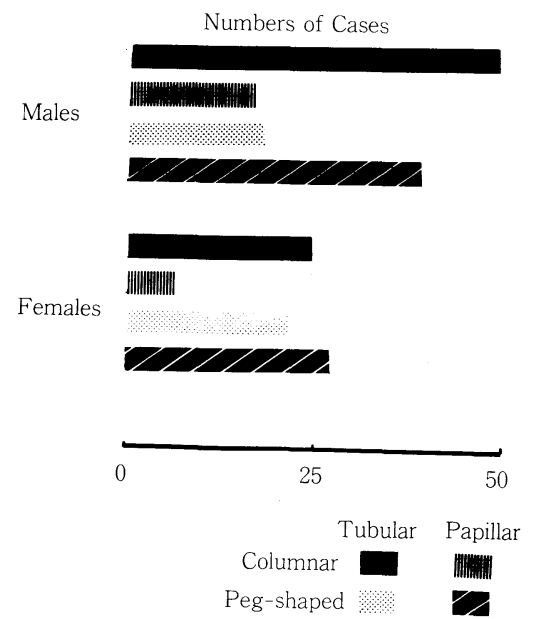

型に分けて分析検討すると（しばしば両細胞型 は混在移行し，量的に比較的優勢な型をもって その症例を代表させた）

腺癌の細胞型亚型と発生部位の関連について の分析は, Table 3 に示すようで, 症例の偏ら ない男性例で，棍棒状細胞型は有意に末梢に多 く発生している。又癌組織像の多彩であるのを 特徵とする肺癌では, 単一な癌組織像のみから 成ることは少いが, , 7),11) 他癌組織像への移行は 男女とも円柱状細胞型の方に有意に屢現れてい る(Table 4 ).

\section{肺腺癌の電顕像 :}

Micro-villiや分泌顆粒をもつもの，グリコーゲ ンを多量にもつものなどがしばしばみられるが, 細胞質内に lamellar bodyをみるものもあり，そ
Fig. 7. Growth pattern of the lung cancer into adjacent lung tissue.

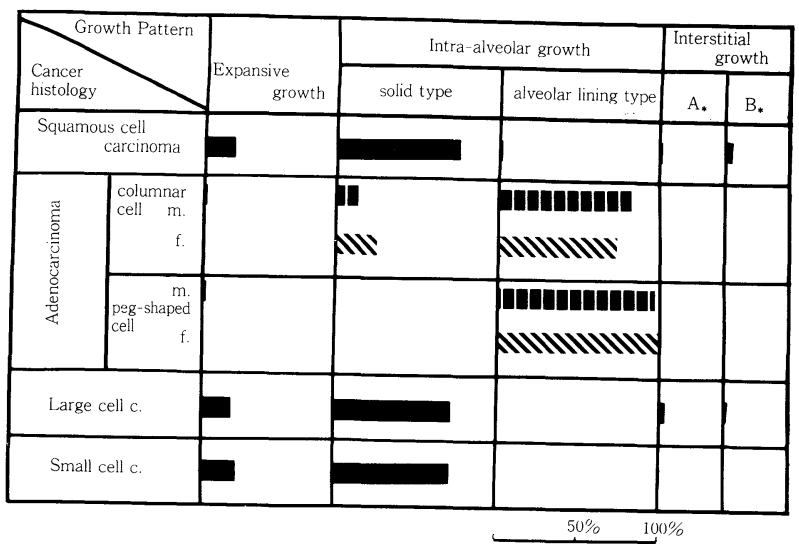

* A perivascular or peribronchial lymph space

* $\mathrm{B}$ perivascular or peribronchial connective tissue
の細胞の厚切り光顕像は必ずしも円柱状, 棍棒 状両細胞型の何れとも限定出来ず, 細胞質内小 器官, 細胞表面の微細構造などは光顕像からの 推測を超えた多彩な像がみられ，扁平上皮癌細 胞の特徵を表す像もみることが出来た。

\section{細胞質内CEAの検討：}

詳細については各癌組織像別に報告する予定 である。腺癌における発現は, 細胞型とも関連 せず，同一形態とみられる細胞でも必ずしも同 様の発現はみられず全く不規則であった。 腺癌の組織構築像を乳頭状, 管状に分け, 夫 夫の像と細胞型亚型とを組合せ比較すると, (Fig. 6 ) 円柱状細胞型ではやや管状が多く，棍 棒状細胞型では乳頭状がやや多い傾向を示した が, 特定の細胞型と組織構築との組合せはみら 
Fig. 8. Age distribution and histological types of lung cancer (peripheral origin, surgically resected cases)
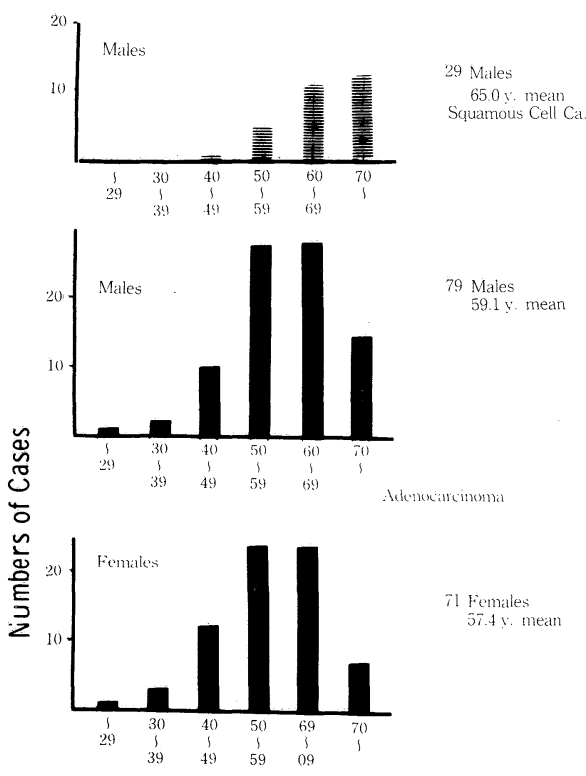

Age groups
Fig. 9. Cell types in adenocarcinoma of the lung and age (surgically resected cases)
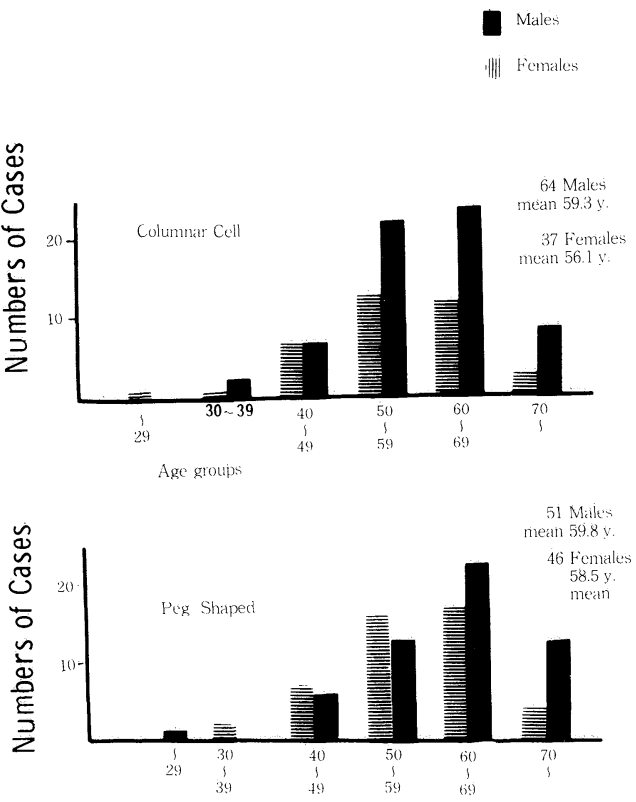

Age groups:

みとめられた。

腺癌の細胞型垔型と年龄との関係は Fig. 9 に

\section{腺癌の肺内進展様相 :}

肺野の癌巣発育尖端部における癌組織像と, 進展様相との関連については Fig. 7に示すょう に，原発性肺癌では圧倒的に肺胞内浸潤性の進 展が多く，肺胞壁を破壊することなく，隣接の 肺胞へと進展することの屢々であるのが特徵で ある.とくに腺癌では, 円柱状細胞型でcribriform typeのものの腔内充実進展が僅かにみられるが, 棍棒状細胞型では男女を問わず 100\% が壁被覆 型をとっている。

\section{腺癌の発生年齢：}

肺内発生例については手術適応が年齢によっ て異るため，末梢発生例についてのみ比較検討 した.Fig. 8 に示すように, 扁平上皮癌例の平 均年齢は65歳, 発現のピークは70歳以上のとこ ろにあり，腺癌例では，50６9歳にピークがあ $\eta$ ，男女間に有意差はなく，平均年齢は男 59 歳, 女57歳で，扁平上皮癌例との間に夫々有意差が 示すように, 男女間にも, 細胞型の間にも, 何 れも有意差はみとめられていない。

末梢初期腺癌巣の 1 例の所見 (Fig. 10)：肺の 大細胞癌例で剔出した46歳女性肺の肋膜直下に, 独立した0.7 mmの病巣が偶然発見された。細気 管支の一方には扁平上皮化生像がみられ, 他方 には腔内に突隆する暗調棍棒状癌細胞の乳頭状 増殖像をみとめた。この癌細胞巣は細気管支壁 から隣接の肺胞へ僅かに浸潤し, 浸潤部では明 かるい立方形の癌細胞がみとめられた。两かる い癌細胞はグリコーゲンに富み, 又暗調細胞に は胞体内にときに粘液を容れているのがみられ， 円柱状, 棍棒状細胞は僅か $1 \mathrm{~mm}$ に満たない病 巣でも複雑に混在していた。この病巣の周囲に は線維化, 痽痕などの病変をみとめていない。 
Fig. 10. Small adenocarcinomatous focus.

A. low-power, Papillary proliferation of dark peg-shaped cancer cells.

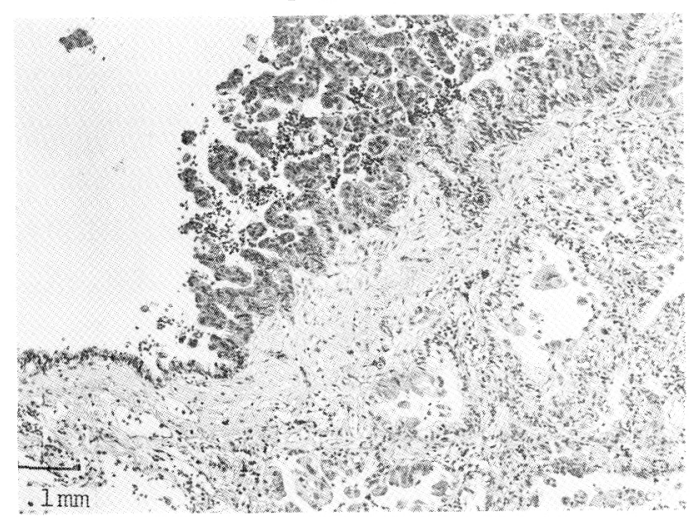

B. high-power, Both clear columnar cancer cells and dark peg-shaped cancer cells invading surrounding alveoli can be seen.

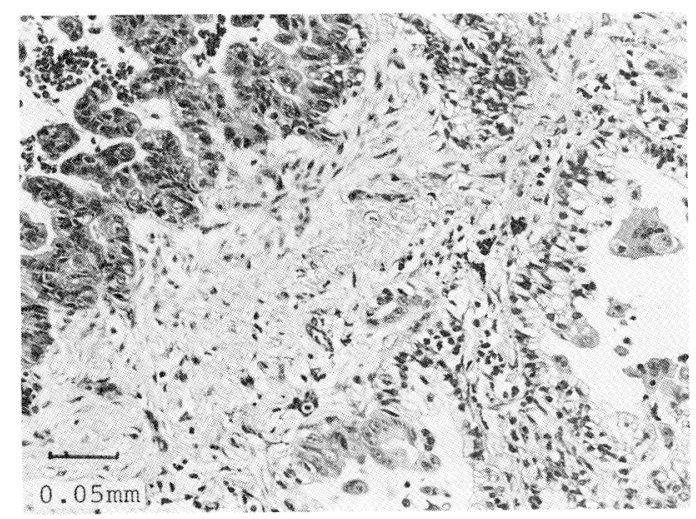

考察とまとめ

肺癌の発生と喫煙との関連についての報告 一一主として疫学的検討——多く, 聏平上皮 癌，小細胞癌の発生と喫煙との関連の密な点に ついてはほぼ異論のないところであろう!1212)ー15) 一方女性肺癌に関しては, 腺癌例の多いこと, 喫煙との関係が明確でない点の報告はみられる が, 12, 16) -19)男性の腺癌発生に関卞る喫煙の影響, 肺癌組織像の男女差は, 果して個体の性差に上 るものか，契煙その他の外的発生要因に帰すへ きであるのか必ずしも現在明確にされていると はいえない。

発生要因と肺癌組織像との関連を考える際に
問題となるのは肺癌組織像の多様性, しかも増 殖過程とともに一層多様化する点である.', 6), 8), 11 多様化の進んだ剖検例，榆索量の少い生検例検 討ではなく，手術剔出例を材料としたことで， 発生からの時間的経過毛比較的短かく, 癌組織 像の多様化も未だつよくはない，などの点から， 今回の検索成績では発生要因と癌組織像との関 連が比較的明瞭に分析し得た。即ち喫煙者にお いては, 扁平上皮癌発生の相対危険度が有意に 高かったが, 腺癌発生に対しては, 男女とも喫 㷬の影響は有意ではなかった。癌発生の様相に 男女差がみられる場合, 内分泌要因を含めた内 的要素の演ずる役割がまづ考慮されねね゙ならな い。女性例では, 喫煙習慣により, 男性と同様 に扁平上皮癌の発生をみるか否かが当然問題に されよう。自験例では女性喫煙例に乏しいため, 八ワイ, ならびに東京都養育院付属病院の女性 喫煙者例を檢討し，内的要因の関与はあまり問 題にならず，男性と同様の傾向を示しているこ とがみとめられた。いわ切る女性型肺癌と呼ん でいる腺癌の発生には, 喫煙など直接気道上皮 への外的刺戙は関連しないといい得る一方, 同 様の外因が加われば，男女にかかわらず同様の 組織型の肺癌が発生方る, ともいい得る。

末梢発生例についてのみの比較であるが, 扁 平上皮癌の発生年齢と, 腺癌のそれとの間には 有意差があり，腺癌の方が男女とも若年側にず れている。一般に全肺癌例の年秢に男女差があ るのは性による発生の差ではなく, 恐らくは発 生要因を異にすると考元られる扁平上皮癌と腺 癌の発生年龄の差と考えることが出来上う。

肺腺癌の発生細胞：

実験動物においては, 経気道的ではない発癌

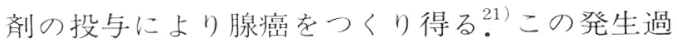
程でactiveな反応を示し, 且又七トの腺癌の細 胞形態にも類似性を示すのがclara細胞である。 又一方棍棒状の形態を示し細胞質内に lamellar bodyをもつのを特徵とするII 型の肺胞上皮細胞 も, 実験癌, 七トの腺癌の発生細胞の一つとし て問題にされ, 癌細胞内の lamellar bodyの存在 がその理由とされている. 24) -26) 又一方細胞形態 の多様性から多分化能をもつ細胞の存在を考之 
るものもある!

検索成績の項ですでに述べたように，腺癌の 細胞型亚型も同一症例内でまざり合っているこ とが多く, 又電顕像も光顕像以上に極めて多彩 で，多方向への形態分化の像がうかがわれた。 癌細胞にみられる, ある形態学的特徵をとら之 て、一る細胞内小器官の存在のみが挙げられ ることもあるが-—その形態分化の像から，

これと類似の構造をもつ細胞に直線的に起源を 求めようとするのは, 肺腺癌のみに限らず好ま しくはない6. 細胞が, 腫瘍化してからのち, 非 腫瘍性の増生像を遥かに上迴る多彩な形態分化 を示す点は，すでに田内らが1954年肺癌につい て報告して以来強調して来ている ${ }^{8), 11)}$

肺腺癌は，呼吸上皮系のどの細胞からも発生 し得るし, 又増殖進展とともに多彩化しうると 考える。これまでの成績から，比較的肺門に近 い部からの発生, 比較的末梢の気道からの発生 という傾向は形態分析の結果からいい得る。末 梢にみられた初期腺癌巣の観察からも，1 $\mathrm{mm}$ に満たない癌巣においてすでに多彩な細胞像が みられている。

肺癌組織分類におけるいわゆる細気管支肺胞 上皮癌について：

日本肺癌学会の組織分類では, 腺癌の乳頭型 の中の一型としている ${ }^{28)} \mathrm{WHO} の$ 分類では乳頭 腺癌と併列してこの分類名があげられているが, この併列 2 者は同一の群とも考之られるとし， 細胞型, その分泌能など種々あることが付記さ れている.29)

乳頭型という表現について考えると, 肺胞壁 を自然に内べりするように進展する像は, 肺胞 壁の正常構造に照らして，一見肺胞腔内に小突 起状に出てはいるが真の乳頭状増殖とはいえな い場合が多い。細胞型との関連では自験例では 円柱状細胞型では管状が多く，棍棒状細胞型で はやや乳頭状が多い傾向を示している(Fig. 6).

腺癌の発育尖端の進展様相は，ほぼ $100 \%$ 近 くが細胞型にかかわらず肺胞内浸潤性で, 肺胞 壁を内べりする進展を示すことがたしかめられ ている(Fig. 7 ).

果して細気管支肺胞上皮癌と組織分類し得る
ものがあるか否かについては若干の報告があり， 電顕所見からつよく特定の細胞を起源として認 めるものもあり, 又一方, 臨床経過の特徵によ $\eta こ の$ 型の存在を主張するものもある。, 22),24),27) 歴史的に原発巣がはっきりしないうちに, 肺 野に撒布性の病巣が出現するという点が特徵と してあげられ，その転移経路についても種々議 論がなされ，とくに肺の血管系の複雑さもこれ にかかわって今日尚問題が多く残されている。

いずれにしても, 肺癌の組織分類はあくまで 細胞ならびにその配列形態によるべきで，転移 の様相の特異性を反映させることは次元が異る と考える。

細胞型からしても, 進展様相からしても, 腺 癌の亜分類の一つとして“細気管支肺胞上皮癌”, の名のもとに形態学的に抽出出来るものはない と考える。

すでに我々は, 肺癌を男性型, 女性型に 2 大 別し，とくにそのうち女性型肺癌としたものを 中心に今回は考察を進めて来た。これまでの社 会の習慣や実績から, 女性肺癌例の大部分を占 めるという意味であったが，種々分析の結果， 発生要因, 年齢, 優勢な癌組織像を異にする, などの所見により, いわゆる男性型とほぼ一線 を劃するものの，生物学的な性差によるもので はなく，生活環境の差に因するものと考えられ た。条件が同じであれば, 発生年齢も, 細胞形 態など男女の差なく同様に発生することがたし かめられた。

女性の喫煙習慣が今後男性のそれに時代とと もに近づくならば，もはや女性型肺癌の名は全 く無意味となるとも考えられる。

この女性型肺癌としたものの発生要因から, 喫煙は除かれるべきであるという点は今回の検 討で明瞭となったが, 一方この型の癌の発生機 序, とくに人の症例については未だ明きらかで はない，間接的に肺胞へ排出される物質の影響, 又末梢気道上皮における代謝一とくに脂質代 謝—の問題など今後の検討課題が多く残され ている.

稿を終るにあたり，総会における特別講演の機会を与 
えて下さった第24回日本肺癌学会会長西本幸男教授に御 礼申し上げます。

又 4 半世紀を超えて終始御指導賜った恩師田内久先生 に深い感謝を捧げると共に, 症例ならびに情報提供を快 よくお許し下さった, 開院以来の愛知県がんセンタ一病 院胸部腫瘍グループの諸先生方, 又臨床検査部一同の協
力に深く感謝致します。

本研究は日本専売公社委託研究費の補助をうけた。

本論文の内容は, 第24回日本肺癌学会総会において特 別講演として発表した。

\section{文献}

1）瀬木三雄, 栗原 登, 石川七郎, 他: 肺癌と契 煙についての疫学調査. 肺癌 $19: 157 \sim 165$, 1979 .

2）日本病理剖検輯報; $20,21,22,23,24$ 輯, 日本病 理学会編, 日本病理剖検輯報刑行会, 1978, '79, '80, '81, '82, 東京.

3）佐藤秩子, 浅井喜久子, 田内 久: 肺癌組織像 と喫煙を中心とした発生要因の分析. 肺癌, 14 : 13-19, 1974 .

4）佐藤秩子：肺癌治療における隘路——臨床病理 の立場から一。目胸, 37:199-204, 1978 .

5）佐藤秩子, 田内久:癌とその宿主, 一加齢と 生活条件をめぐって一。肺癌, 医学のあゆみ, $9: 355 \sim 360,1976$.

6）佐藤秩子：肺癌に関する病理学的知見の現況， 医薬の門, 20:230-234, 1980 .

7) 田内人, 牛島 宥, 佐藤秩子: 腫瘍の肺内転 移並びに進展様相, 癌の臨床, 6:452-454, 1960.

8) 田内 久, 三浦馥, 折茂謙一, 他: 肺癌の発 育進展についての病理学的考察. 癌の臨床, 14 : $24-30,1968$.

9）佐藤秩子, 三浦、馥：各種要因による肺内の癌 進展様相の組織学的検討, 癌の臨床, 14:231$234,1968$.

10）佐藤秩子, 田内 久: 肺癌の発育増殖様相に関 する病理学的研究——肺野癌の発育進展様相一. 肺癌 $22: 266,1982$.

11) 田内久, 林活次, 中村 時, 他: 原発性肺 癌の病理。名市大医誌 5:83-103，1954.

12) Hinds, M. W., Stemmermann, G. N., Yang, H. Yi. : Differences in lung cancer risk from smoking among Japanese, Chinese and Hawaii women in Hawaii. Int. J. Cancer 27 : 297-307, 1981.

13) MacLennan, R., Costa, J. D., Day, N. E. et al. :
Risk factor for lung cancer in Singapore Chinese. Int. J. Cancer, 20:854-860, 1977.

14) Chan, W. C. and Calbourne, M. J. : Bronchial cancer in Hong Kong 1976-1977. Brit. J. Cancer, $39: 182-192,1979$.

15) Tauchi, H. \& Sato, T. : Pathological investigation on the relation between lung cancer and smoking. Indian J. Chest Dis. Allied Sci., Special No. on Smoking \& Health. 105-114, 1982.

16) Lombard, H. L. and Huyck, E. P. : An epidemiological study of lung cancer among females. Growth, $32:$ 41-56, 1968.

17) Wynder, E. L., Covey, L. S. and Mabuchi, K. : Lung cancer in women; present and future trends. J. Natl. Cancer Inst., 51 : 391-401, 1973.

18）シンポジウム「女性の肺癌」中部肺癌学会報告, 肺癌 $22: 594,1982$.

19) Kennedy, A. : Relationship between cigarette smoking and histological type of lung cancer in women. Thorax, 28:204-208, 1973.

20) Carter, D. \& Eggleston, J. C., Tumor of the lower respiratory tract, In ; Atlas of Tumor Pathology, Fac. 17, 1980. A. F. I. P. Washington, D. C.

21）蟹沢成好：末梢性肺癌——ウスによるその発 生機序と組織発生の研究. 肺癌 20 : Suppl., 35 -51, 1980.

22）小形岳三郎, 土井幹雄, 鈴木惠子, 他 : clara cell carcinoma一その組織像と顆粒の分布, 肺癌, $22: 321,1981$.

23) Greenberg, S. D., Smith, M. N. and Spjut, H.J. : Bronchiolo-alveolar carcinoma,cells of origin. Amer. J. Clin. Pathol., 63 : 153-167, 1975.

24) Kuhn, C. : Fine structure of bronchiolo-alveolar cell carcinoma, Cancer, $30: 1107-1118,1972$. 
25) Kimula, Y. : A histochemical and ultrastructural study of adenocarcinoma of the lung. Amer. J. Surg. Pathol., 2 : 253-264, 1978.

26）鳥潟親雄, 影山圭三：II 型肺胞上皮癌の電顕的 検討, 肺癌 $22: 322,1981$.

27) Nash, G., Langlinais, P. C. and Greenwals, K. A. : Alveolar cell carcinoma : Does it exist ? Cancer, 29: 322-326, 1972.

28）日本肺癌学会組織分類再検討委員会：肺癌の組 織学的分類, 肺癌, 18：101-121，1978.

29) World Health Organization : Histological Typing of Lung Cancer, 2nd, ed., Internatl. Histol., Class. Tumors. No. 1. Histological Typing of Lung Tumors, WHO, Geneva, 1981, p. 25 -26 .

30）鈴木定雄：腫瘍の肺胞内転移機構に関する実験 病理学的研究. 名市大医誌 $7: 206-220,1957$.

31）青木貞章：虚脱療法と肺血管系特に気管支動脈 及び肺動脈との関係, 肺結核治癒の病理一その 機転及び過程一, 青木貞章編, 医学書院, 東京, 1955 , p. $3-49$.

32) 影山圭三, 清水興一, 後藤政治 : 病理学的にみ た肺癌の特徵, 慶應医学, $41: 323-336,1964$.

33）影山圭三, 上村 等：いわゆる Alveolar Cell Carcinoma (or Tumor) の 1 剖検例, 胸部外科 $6: 458-462,1953$. 


\section{The So-called "Female type" of Lung Cancer}

\section{Tsuneko Sato}

Department of Pathology \& Clinical Laboratories,

Aichi Cancer Center Hospital,

Nagoya, JAPAN

Morphological analysis of the so-called "female type" of lung cancer has been made compared with the "male type", concerning the relationship of the cancer histology, age, sex, and site of primary growth with special reference to the smoking habits of the patients. At present, in Japan, the majority of female lung cancer belongs to the so-called "female type". Those cases did not have remarkable smoking habits. The dominant histology of this type was adenocarcinoma, originating in the peripheral portion of the lung. Even in male cases of adenocarcinoma, characteristics similar to those of female cases were noticed concerning the site of origin, age, and also ageadjusted relative risk associated with smoking habits.

About 130 female cases of lung cancer in Hawaii and 28 cases in Tokyo Metropolitan Geriatric Hospital were also examined. A majority of female smokers showed squamous cell carcinoma or small cell carcinoma which was similar to our "male type" cases.

Adenocarcinoma was subclassified into two cell types as follows: 1. columnar cell type, 2. peg-shaped cell type: The peg-shaped cell type of adenocarcinoma appeared with significant frequency in the peripheral portion of the airway.

The growth pattern of adenocarcinoma foci into surrounding lung tissues showed lining growth along the alveolar walls. The author doubts the existence of "bronchioloalveolar cell carcinoma" as a distinct morphological entity in adenocarcinoma. 